の交差地域の構造を総括しているのであるが，こ こで塑性変形の重要性を挙げ後は将来の研究にま かせている。読者は日本海とのつながりを考える がこの点は残念乍ら本書では割愛されている。

この章の終りに交差地域の構造総括なる一項が ある。立体的に見て東西方向の本州弧の下にフィ リッピン海プレートが北上し，更にその下に七島 弧が南北方向に立体交差している。伊豆半島だけ が衝突していると言った狭い範囲のものではなく， 七島山脈がその幅全体にわたって本州弧と衝突し， これと交差しているのだと言う。そして交差地域 の南西縁は渥美半島あたりからとし, 新しい考え であるスラブの形を予想し, 塑性変形からサイレ ント・アースクェイクなる概念をとり上げている。 結論的に言うと, 著者はフォッサマグナの地䒴 の事実をもとに, 日本海側は糸魚川から柏崎まで と, 太平洋側は渥美半島から犬吠崎までという広 範囲の台形地域の地質構造を, プレート理論の進
歩の先取りをしつつ論述している。ナウマンが日 本中央部にみつけた大きな溝は，100 年を経て, 立体的にその姿を復活した。地学専門家必携の書 物であると同時に一般の方々にはやや専門的であ るが，地質の研究者の時閒概念はこういうものな のか, 空間概念はこういうものなのか, 立体的地 質学と言える本書の一読をここにお勧めする。紹 介者は読後毎晚日本列島の夢を見ている。誠に夢 を誘う面白い本である。

(有田忠雄)

\title{
$\diamond$ 新刊紹介
}

-小林和男 : 生きている海洋底一一海底 2 万哩地 球科学の旅一一平凡社, 1995 年 3 月, 281 ヘ ージ，2,900円。

-大沢雅彦・大原 隆編 : 生物一地球環境の科学 南関東の自然誌—— 朝倉書店, 1995年 4 月，198ページ，4,944円 